DOI:10.30842/ielcp230690152368

\author{
Luka Repanšek \\ (University of Ljubljana, Slovenija)
}

\title{
NOTULAE BREVES INDO-IRANOLOGICAE
}

The contribution consists of three short notes on various aspects of Indo-Iranian historical grammar. $\$ \mathbf{1}$ aims to explain the aberrant Young Avestan Nsg. m. endings of the active present/aorist participle as the result of inner-Avestan reanalysis. $§ 2$ provides a renewed attempt at inventing a convincing scenario for the massive remodelling in Vedic $-v /$ mantand -vas- stems, justifying it as an arguably purely inner-Vedic process. § $\mathbf{3}$ is a brief reconciliatory note on the definite origin of Avestan \#c/juиasequences. Finally, $\$ \mathbf{4}$ elaborates on a sidenote proposal made by the author in 2018 on the source of the length in Young Avestan $t \bar{u}^{i}$ riia-.

Key words: Avestan, Vedic, Indo-Iranian, historical morphology, historical phonology, inter- and intraparadigmatic levelling.

Л. Репаншек

(Люблянский университет, Словения)

\section{Notulae breves Indo-Iranologicae}

Работа состоит из трех кратких заметок о разных аспектах индоиранской исторической морфологии. В § 1 предлагается объяснение нестандартных окончаний действительных причастий настоящего времени/аориста в форме именительного падежа единственного числа мужского рода в позднеавестийском, полученное в результате внутрисистемного переосмысления авестийской грамматики. В $\$ 2$ предпринимается новая попытка поиска убедительного сценария обширной перестройки в ведийских основах на -v/mant- и -vas-; ставится под сомнение, что это исключительно внутриведийский процесс. $\$ \mathbf{3}$ представляет собой краткую справочную заметку о точном происхождении авестийских чередований \#c/juиа-. И наконец, в § 4 детально разрабатывается бегло высказанное автором в 2018 г. соображение относительно источника долготы в младоавестийском $t \bar{u}^{i}$ riia-.

Ключевые слова: авестийский язык, древнеиндийский язык, праиндоиранский язык, историческая морфология, историческая фонология, внутрипарадигматическое и межпарадигматическое выравнивание.

\section{$\S 1$. YAv. Nom. Sg. m. of the active present/aorist participle}

The blatant mismatch between the shape of the synchronically productive nominative singular masculine of the $n t$-participle in Old and Young Avestan obviously points to a recent, i.e. Young Avestan innovation and can hardly reflect an inherited pattern. Schindler's seminal work on the problem of YAv. $-\bar{o}$ (as though $<*_{\text {-ah }}<*_{\text {-as }}$ ) and $-q \sim-\bar{\partial}$ (as though $<*_{-} \tilde{\tilde{a}} h<*_{\text {-anh }}<*_{\text {-ans }}$, and in comple- 
mentary distribution matching that of the Apl. m. of thematic and Gsg. of descriptively proterodynamic oblique nasal stems), however, has sought to derive both endings from their respective etymological sources by way of (regular) sound change (see Schindler 1982, esp. pp. 193-195 and 199). Given that both thematic and athematic OAv. - as $<*_{-} \tilde{\tilde{a}} s<*_{-} a(-) n s<$ PIr. ${ }^{*}-a(-) n t^{s}<$ PIIr. ${ }^{*}-a(-) n t s<$ PIE $*_{-} o-n t-s$ $\sim *$-ent-s clearly testify to the fact that the Proto-Iranian postmonophthongisation product of the inherited Proto-Indo-Iranian sequence $* t s$ must have yielded Common Iranian $* s$ only after the equally Common Iranian change of $*_{s}$ to $* h^{1}$ but early enough to have induced the desegmentation process of the preceding nasal in a $* V N \Phi \#$ sequence ${ }^{2}$, neither $-q \sim-\bar{\partial}$ nor $-\bar{o}$ can be in any sensible way derived from *-a(-)nts and *ats (for the latter cf. the Nsg. of $-\bar{a} t-$ stems such as ha ${ }^{u}$ ruuatās 'wholeness' $<*$ harwatāt ${ }^{s}<*$ sarwa-tāt-s) respectively, as this would necessarily require a reverse chronology: PIIr. ${ }^{*}$-ants $>$ PIr. $*_{\text {-ant }}^{s}>$ CIr. ${ }^{*}$-ans $>*_{\text {-anh }}>*_{\text {-a }}$ h $\sim$ PIIr. $*_{\text {-ats }}>$ PIr. ${ }^{*}$-at $>$ CIr. ${ }^{*}$-as $>*_{\text {-ah }}$. It is to be agreed, however, that YAv. $-\bar{o}$, by far the commonest variant of the Nsg. m. ending of originally mobile and immobile $n t$-stems, must somehow continue

$1 / \mathrm{V} \_\mathrm{V} ; \mathrm{R} \_\mathrm{V} ; \mathrm{V} \_\mathrm{R} ; \mathrm{R} \_\mathrm{R}\{-\mathrm{r}, \mathrm{n}\} ; \# \_\mathrm{V} / \mathrm{R}\{-\mathrm{r}, \mathrm{n}\} ; \mathrm{R} \_$\#.

${ }^{2}$ The chronology relating the Common Iranian changes that affected $*_{s}$ and $*$ ts can in my opinion be envisaged as follows: 1$) *_{s}>* h$ (vide supra for the conditioning environment);2) $\left.*_{s}, *_{z}>\emptyset / \#, \$ \_t s, d z ; 3\right) *_{t s}>*_{s} / s \$$

4) $\left.* t_{s}, * d z, * t f, * d_{3}>*_{s}, *_{z}, * \int, *_{3} / \mathrm{T}(\#), \mathrm{T}_{2} ; 5\right) * t>\emptyset / s, \int_{-}$; 6) retraction of $*_{s}, *_{z}>*_{f} *_{3} /$ [ [ bilabial]_[-dental]; 6) devoicing of $*_{z}$, $*_{3}>*_{s}, * f / \ldots \mathrm{N}$; 7) $*_{t s}>*_{s}, *_{d z}>*_{z} / \ldots$; 8) $\mathrm{N}>\emptyset / \breve{\mathrm{V}}>\overline{\mathrm{V}} \_$_\#. Regarding the relative position of № 7, note that since the sibilant reflexes of the old sibilant affricates *ts $(\leftarrow * t$ ) by way of a Proto-Iranian push chain and $<* t s$ in the course of PIr. monophthongisation process of biphonemic $T S$-sequeces) and $* d z(\leftarrow d \xi)$ must have been dentals rather than alveolars (cf. Kümmel 2007a: 69ff., 194ff. for typology), judging from their subsequent development in Old Persian (where $*_{n}$ and $*_{z}$ are pushed to dental spirants in a polarisation gesture upon the entrance of new retracted $*_{S}^{*},{ }_{z}<* *_{t s w}{ }^{*} d t w$ into the system), and as such could not and obviously did not coalesce with the old sibilants (the dental articulation of $*_{S}$ and $*_{z}$ could after all be and likely was the very result of such preventive strategy), the only decisive point in the relationshiop between $*_{s}>* h$ and $*_{t s}>*_{s}$ is the date of the ultimate coalescence of $*_{s}$ (in as far as the latter is still preserved in conditioned environments and as the reflex of *tst\#) and $*_{s}$, which must logically postdate the former development (exactly such sequence of events being rather expected, given that it would have been the new tripartite opposition $* h: *_{s}:{ }_{s}$ that favoured the subsquent merger in the first place). 
the generalisation of the immobile active participle ending (cf. Schindler, op. cit., p. 199), i.e. *-at-s, inherited in Narten presents, sigmatic aorists and $a$-reduplicated presents.

Taking advantage of this synchronically-motivated morphological generalisation, the possibility presents itself to convincingly account for the aberrant Young Avestan $-\bar{o}$ (with sandhi-induced variant $\left.-a s^{\circ}\right)$ and $-q \sim-\bar{\partial}$ (sandhi form predictably $-a s^{\circ}$ ) as products of a recent analogical development. In this account, the YAv. $-\bar{o}$ is most straightforwardly analysable as a simple retrograde form, based on the synchronic reanalysis of the inherited sequence ${ }^{*}$-as (in its original distribution as the default ending of all immobilia) <

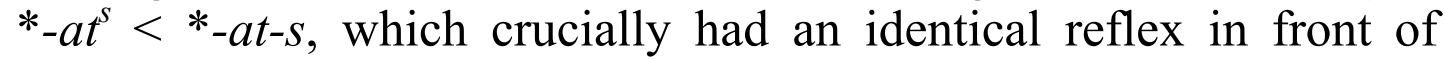
sandhi-inducing clitics, as a sandhi form of $*_{-} \bar{o} \sim *_{-} a s^{\mathrm{o}}$. The analogical proportion responsible for such a reorganisation is statable as $-\boldsymbol{a s} \mathbf{s}^{\mathbf{0}}:-\overline{\boldsymbol{o}}=-\boldsymbol{a s}:-\boldsymbol{a s}=\mathbf{x}, \mathbf{x} \Rightarrow-\overline{\boldsymbol{o}}$.

Such a redistribution would have quite naturally exerted enough motivational pressure on the parallel ending $*_{-} \tilde{\bar{a}}$ to induce an analogous synchronic response: $-\boldsymbol{a} \boldsymbol{s}^{\mathbf{0}}:-\overline{\boldsymbol{\sigma}}=-\tilde{\overline{\boldsymbol{a}} \boldsymbol{s}}:-\tilde{\overline{\boldsymbol{a}} \boldsymbol{s}}=\mathbf{x}, \mathbf{x} \Rightarrow-\tilde{\overline{\boldsymbol{a}}}$ (note that an analogical influence from the side of the accusative plural of masculine $a$-stems is not a likely source of $*_{-} \tilde{\tilde{a}}$ due to the essential difference between the two case functions). The process was obviously early enough to subject the new $*_{-} \tilde{\bar{a}}$ to the process of denasalisation to $*_{-} \bar{\partial} /\{-\mathrm{N}, \mathrm{j}, \mathrm{h}\}$ \# (cf. de Vaan 2003: 503), which more generally encompassed both $*_{-} \tilde{\tilde{a}}>*_{-} \tilde{\tilde{a}} h$ as the reflex of the Proto-Indo-Iranian sequence $*-\breve{a} n s$ as well as $* \tilde{\bar{a}}$ that appears in the Young Avestan outcome of $*_{\partial} \tilde{r} \Phi<*_{r} N \Phi \#$ (cf. PIIr. *- ${ }_{-} \tilde{r} \tilde{s}>*_{-}(\partial) r_{r}^{\tilde{s}}$

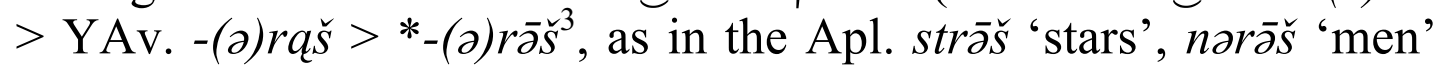
etc.). As the last step in the chain of events that disrupted the inherited pattern in the nominative singular of masculine $n t$-stems would have been the rise of synchronic interchangeability of the two endings, so that, e.g., YAv. $h q$ 'being' $<$ PIIr. *s-ánt-s $(\leftarrow$ PIE * $\left.H_{1} e ́ s-o n t-s\right)$ and usō 'wishing' < PIIr. *ut-ánt-s ( $\leftarrow$ PIE *uék-ont-s) both appear as grammatically acceptable continuations of originally mobile active $n t$-participles.

\section{$\S$ 2. Towards an alternative account of the intraparadigmatic levelling in Vedic -vas- and $-{ }^{v} /{ }_{m}$ ant-stems}

The synchronic shape of Vedic and Classical Sanskrit paradigms continuing the PIE active perfect participle in *-ues-/*-us- and

\footnotetext{
${ }^{3}$ With partial, probably solely graphematic, corruption to $-\bar{\partial} u \check{s}$.
} 
possessive adjectives in *-uent-/*-unt- displays the following aberrancies in regard to the diachronically expected forms:

- The presence of a nasal in the strong stem of the active perfect

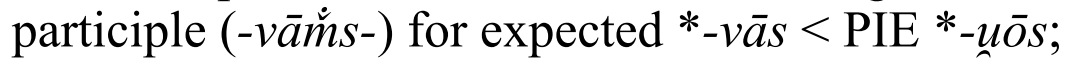

- Lengthening in the Nsg. $\mathrm{m}$. of the possessive adjective $(-v / m \bar{a} n)$, including the dentalless sandhi form (-vāmms-);

- The middle stem of the perfect participle in -vat- $\left(<*_{-}\right.$unt $\left._{0}\right)$ for PIE *-us-;

- Vsg. m. of the possessive in -vas for expected *-van $<*$-uent.

The intrusion of the nasal into the strong stem of the originally purely sigmatic form of the perfect active participle has, as is well known, also influenced the structurally parallel stems of the comparative in $-y \bar{a} \dot{m} s-<\mathrm{PIE} *_{-}$-ios- as well as the two lexical isolates, viz. púmas- 'man' (strong stem púmā̆ัns- for probably expected *púmās-) and, to a minor extent, anad-váh- 'ox' that displays a Nsg. anad-vắn instead of the expected *-vát $<$ PIE *-uógh ${ }^{h}-s$.

Given the almost even share of analogically remodelled forms in each of the respective paradigms under discussion, it seems obvious that the synchronic situation must have arisen as a consequence of their prolonged mutual influence ${ }^{4}$. The initial impetus, I would

\footnotetext{
${ }^{4}$ Hoffmann's proposal (1976: 555-556, cf. also Lipp 2009: 222, ft. 173) that the specifically Vedic behaviour of $v /$ mant-stems is the result of subsequent analogical remodelling of an inherited pattern Nsg. m. ${ }^{*}-w \bar{a} s$, strong stem *-want-, weak stem *-wat, Vsg. *-was implies that a PIE sequence *-uent-s would have regularly developed to *-ues. While the idea of the auslauting sequence $* t s$ resulting in ${ }^{*} s s$ could perhaps be defended on the basis of the treatment of this cluster in a post-vocalic environment (as assured by the behaviour of dental stems such as *népōs $\leftarrow{ }^{*}$ népos $<$ *néposs < *nép-ot-s etc.) - but note that the Nsg. m. of the present participle strongly speaks against the PIE version of a miles-type development in a post-consonantal coda - , it is less than likely that an assumed $*_{-u e n s s}$ would yield *-uens by compensatory lengthening (the last

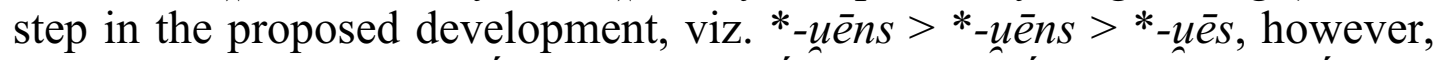
is unproblematic, cf. *més 'meat' $<*$ méms, Apl. *'gốs 'cattle' $<*$ gốns by Schindler's Law). Such a starting point would also completely obscure the reason(s) behind the analogical process responsible for the reshaping of the Nsg. m. of the possessive adjective in Iranian, since on this account one would be forced to justify an apparent remodelling in the so obviously moribund, peripheral and hence surely archaic relational ${ }^{*}$-wans $<*$-want $t^{s}$ $<*_{\text {-want-s, whereas }}^{*}$-wa $\bar{s}$, which given its association with the highly productive category of possessives in *-want- must easily be secondary (see Jamison 1991: 99-100 for a convincing account), would have to be seen as primary. Note, however, that non-categorical remodelling of the
} 
claim $^{5}$, for the gradual harmonisation of the two inherited declensional patterns must have been provided by the synchronically established correlation between the NApl. neuter forms. Their structural comparability, however, was the result of two older analogical processes (one of them apparently as old as Proto-IndoIranian), both of which are well known:

1) The inherited PIIr. neuter plural $*_{- \text {wanti }}<*_{-}$uent- $H_{2}$ (or possibly $*$-uont $-H_{2}$ ) received an analogically motivated lengthening of the suffixal vowel on the model of other inherited neuter collective plurals of suffixed stems. ${ }^{*}$-wanti $\rightarrow{ }^{*}$-wānti (parallel to and by analogy with the treatment of the NApl. ntr. of nasal stems, Iranian witnesses to a additionally remodelled $*_{-} w \bar{a} n t>*_{-} w \bar{a} n=\mathrm{Av}$. -uuqn);

2) The ending of NApl. sigmatic neuters ${ }^{*}$-wās $<$ PIE $*-u \overline{o s}{ }^{6} \leftarrow$ *-uos- $\mathrm{H}_{2}$ was subjected to the uniquely Indo-Aryan across-the-board restructuring of the NApl. ntr., which involved the accommodation of the inherited sequence to the synchronic structural model provided by the NApl. ntr. of nasal stems in $-(v / m) \bar{a} n i{ }^{7}$ so that ${ }^{*}-w \bar{a} s \rightarrow{ }^{*}-w \bar{a}-n-s-i>-v \bar{a} \dot{m} s i$.

The now synchronically apparent parallelism between the two nominative-accusative neuter plural cases levelled the lengthened grade of the Nsg. m. of the active perfect participle into the

inherited ${ }^{*}$-wans $\rightarrow{ }^{*}$-wās seems to be Proto-Iranian, seeing that 1$)$ in contradistinction to the remodelling in the active present participle, which only affects Young Avestan, $-u u^{a} \stackrel{\circ}{a}$ as the regular Nsg. m. of the possessive adjective in -uuant-is already the norm in the Old Avestan corpus and as the situation in the case of the $n t$-participle instructs, not the result of Young Avestan overlayering; 2) the same situation obtains in Old Persian, where the synchronic reanalysis of the active present participle *tunuwant'strong' <*ta-nw-ánt- as a stem in *-want- has yielded a Nsg. m. tunuva $\bar{a}=$ tunuva ${ }^{h}$.

${ }^{5}$ But see Jamison 1991 for a radically different account.

${ }^{6}$ Note that since Szemerényi's Law was inapplicable to $*_{-} V_{s} \Phi \#$ sequences, the lengthened grade of any stem not terminating in a resonant must be the result of an analogical extension from the period in Proto-Indo-European that already possessed enough critical mass of the purely phonetically motivated lengthened grades in the nominative singular / collective for these to be synchronically perceived as morphologically distinctive and consequently grammaticalised.

${ }^{7}$ Itself remodelled intraparadigmatically from the inherited $*_{-}(v / m) \bar{a}<$ PIE $*_{-}(u / m) \bar{o}<*_{-}(u / m) o n-H_{2}$. 
possessive adjective and enabled the reciprocal transference of the nasal from the latter to the former:

$$
\begin{aligned}
& { }^{*} \text {-wānsi : }{ }^{*} \text {-wānti }={ }^{*} \text {-wās }:{ }^{*} \text {-wants }=\mathrm{x}, \mathrm{x} \Rightarrow{ }^{*} \text {-wānts } \\
& { }^{*} \text {-wānti : *-wānsi }={ }^{*} \text {-wānts : }{ }^{*}-w \bar{a} s=\mathrm{x}, \mathrm{x} \Rightarrow{ }^{*} \text {-wāns }
\end{aligned}
$$

(note that after the loss of extra-syllabic consonants in pre-pausal codas the sandhi-induced variant of these and all other $n t$-stems was analogically adapted to reflect an underlying $n s$-sequence ${ }^{8}$ ).

Once these two cardinal points of structural equatability were established, the intrusion of the nasal into the strong stem of the perfect participle $\left(*_{\text {-wānts }}: *_{\text {-wa }}\right.$ ans $=*_{\text {-want- }}: *_{\text {-wa }} \bar{s}_{-}=\mathrm{x}, \mathrm{x} \Rightarrow$ $*_{-w}$ a $\left.n s^{-}\right)$and the generalisation of the sigmatic suffix in the vocative singular (most straightforwardly after the elimination of extrasyllabic consonants in \#\#codas: ${ }^{*}-w \bar{a} n:{ }^{*}$-wān ${ }^{<-w a ̄ n t s}={ }^{*}$-was : ${ }^{*}$-wan ${ }^{<{ }^{*} \text { want }}=\mathrm{x}, \mathrm{x} \Rightarrow$-was) were a more or less natural consequence, as was the strategy of the zero-grade sigmatic suffix *-us$*_{-}^{*} u z-$ to copy the middle stem of the possessive adjective $\left({ }^{*}\right.$-wat- $\sim$ $*$-wad-) $)^{9}$ rather than follow the general manoeuvre in repairing the phonologically regular but morphonologically unacceptable changes on the morpheme boundary before terminations beginning with a consonant by applying $t \sim d$ as the synchronic avatar of the (apical) postalveolar/retroflex sibilant (**-uḍ-bho $\left.{ }^{o} * *-u t-s \underline{u} u\right)$.

\section{§ 3. A note on the Avestan sequences cuиa-, juua-}

YAv. cuuant- '(having) how much; how great' < PIIr. *tciHwant- < PIE * $k^{u} i$ - $H_{1}$-uent- = Ved. kivvant- 'id.', ascuua- 'shank' $<$ PIr. *astciHwá- < PIIr. *astciHwá- < *asttciHwá- (= Ved. așthivá(nt)-; for the etymological connection see Lubotsky 2002) and an already OAv. example of juua- 'alive' < PIIr. *dkiHwá- < PIE $* g^{u} i H_{3}-u o_{-}=$Ved. jīvá- (including the verbal base juua- < ${ }^{*} g^{u} i H_{3}-u(-) e ́ l o ́-/=$ Ved. jóva-/ and its younger, analogical external derivative YAv. juuaiia- $<* d \measuredangle i H w$-ája-) have been observed to display a peculiar reflex 〈uu of the inherited sequence $* i H w$. It has been suggested by de Vaan (2003: 246, cf. Kümmel 2007b: 274, 275) that this sequence must reflect shortening of the otherwise expected $* \bar{i} w$ (as would in fact be in line with YAv. examples of $u j$ $<* \bar{u} j$ ), upon which the short front vowel would have been absorbed into the preceding palatal (loc. cit.). That the sequence remained disyllabic even after the phonetic processes at hand produced the

\footnotetext{
${ }^{8}$ Cf. Hoffmann 1976: 555.

${ }^{9}$ Cf. Jamison 1991, esp. pp. 96-97.
} 
surface forms, is, however, unequivocally demonstrated by OAv. juuā (Y 45.7b; cf. Kellens/Pirart 1988: 156) = [dzuwấ], appearing in the first half-line of an uštauua ${ }^{i} t \bar{\imath}$ metre.

The most economical solution therefore is to assume that unlike Old Persian, which based on the evidence of jiv $a$ - 'alive' matches its Indo-Aryan counterpart perfectly, Avestan never displayed a laryngeal-conditioned length in either of the above examples, having lost the segmental reflex of PIE $* H$ without compensatory lengthening due its inherent heterosyllabicity before a following resonant (see Kümmel 2004 for the general discussion of the treatment of VHT and VHR sequences in Iranian), so that *dkiHwá$>$ *dŁiwá- > YAv. juua- vs. *dtiHwjá- 'relating to a living being'

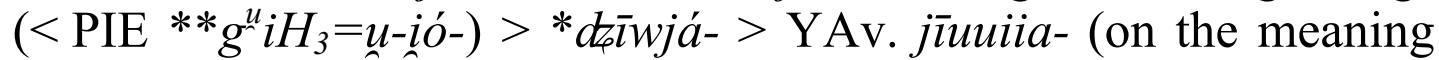
of the latter see Hintze 1994: 112, ft. 112 and cf. Narten 1982: 140; for a different interpretation of the phonological history see Hoffmann-Narten 1989: 78 and de Vaan 2003: 244). Since, however, any unaccented disyllabic sequence $* u w$ with the exception of $\# C R u w^{\circ \prime}$ (cf. OAv. mruiie 'is being said' <*mruwáj $\left.<\mathrm{PIE} * \mathrm{mluH}_{2}-o_{-}-i\right)$ seems to have been subjected to syncopation in Young Avestan (note the likes of YAv. zbaiia- 'to call' <*zuwája-

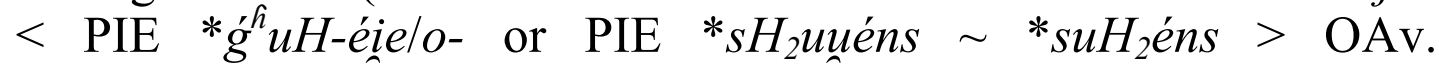
*huwáng(h), modernized to *hwáng $(h)>x^{v} \bar{a} n \dot{g}$ during the Young Avestan period), it seems theoretically possible, although ultimately ambiguous, ${ }^{10}$ that the assimilation of the inherited cluster *iw to *uw was a phenomenon that affected Avestan as a chronologically younger development not bled by the syncopation rule, and on the evidence of related Eastern Iranian forms Khot. juv- = Sogd. [žuw-] $<*$ deiwa- "to live" ${ }^{11}$ conceivably in the course of operation of a

${ }^{10}$ The apparent preservation of disyllabicity in forms like juua- (at least as far as the adjective is concerned, but since root-accentuation of Ved. jîvais secondary, following the pattern of ${ }^{*} C a ́ C-a$ - presents in whose association it was brought synchronically, Av. juua- 'to live' may, however, still be a case in point) and ascuua- in Young Avestan (consider the evidence of Asg. jüm <*dkuwam, ascūm < *astuwwom, both - at least under the most straightforward interpretation - with an originally long $\bar{u}$ as the result of contraction, or, for that matter, YAv. feminine form juiie in Aog. 53 /JamaspAsa 1982: 36/ <* dtuwjai) need not be old, of course, but can be the result of the general Young Avestan change of $*_{j},{ }^{*} w$ to $i j, u w$ postconsonantally, excluding $* \partial w(<* d u w)>* \partial \beta, * h w \sim h j>\eta^{w} h \sim \eta^{j} h$ $/ \overline{\bar{a}} \_\overline{\bar{a}}$, and $* x w \sim * x j\left(<* h u w \sim * h i j / \_V ́\right.$, after the reorganisation of accent placement) $>* x^{w}, * c j$.

${ }^{11}$ Cf. EDIL III s.v. ${ }^{1}$ gai-. 
Common Iranian sound change (comparable to the late but shared developments such as $*_{s w} \sim *_{z w}>*_{s} \varphi \sim *_{z} \beta>*_{s p} \sim *_{z b}$ and ${ }^{*} \theta w \sim$ $* d w>* \theta \beta \sim * \partial \beta$ ).

As is well known, the conditioning environment for this assimilatory process seems to have mostly been a preceding palatal (Young Avestan 〈c〉 and $\langle\mathrm{j}\rangle$ could have still been alveolo-palatal affricates, although by this stage they would have most probably already progressed to postalveolar articulation), which becomes increasingly apparent in juxtaposition with YAv. piuuah- 'fat' < *píHwah- = Ved. pìvas- 'id.' $\leftarrow{ }^{*}$ pi $H-w r<\mathrm{PIE} *$ péiH-url ${ }^{*}$ piHuén-, but cf. duua ${ }^{i} \bar{\imath}$ in Y. $29.5 \mathrm{~b}<* d^{h} H_{1}$-ued $d^{h} H_{2}$. This essential difference in the treatment of Young Avestan / Eastern Iranian $*_{i}[\mathrm{I}]$ in front of a voiced labial-velar approximant depending on the place of articulation of the preceding consonant is of course expected phonetically, given that as a follow-up of the fricative phase in the production of the postalveolar affricate the $i$-sound is most naturally assimilated acoustically to the following approximant in anticipation of the accompanying lip-rounding (probably, though not necessarily, via $\left.\left[\mathrm{t}^{\mathrm{y}} \mathrm{uw}\right],\left[\mathrm{dg}_{\mathrm{y}}^{\mathrm{y}} \mathrm{uw}\right]\right)$.

\section{§ 4. The length in YAv. $t \bar{u}^{i}$ riia- 'paternal uncle' reconsidered}

In Repanšek 2018: 1134, ft. 6, I proposed to see the length in YAv. $t^{i}$ riia- $<*$ ptrwja- as the effect of compensatory lengthening upon the loss of $* w^{\prime}<* w / \quad \mathrm{j}$ as opposed to its preservation and the accompanying shortness in brätruiia- $<*$ brätrawja- $<*$ brātarwja(with regular metathesis $* \partial r>* r \partial / \mathrm{R} \$$,\#), and paralleled with the resegmentation of ${ }^{w}$ in paoriia- $\left(<*^{*}\right.$ pawrija- $)<{ }^{*}$ pawrja- $<$ *paw rwja- vs. hau ruua- $<* h a^{w} r w a-<* h a r w a-$ and not **haoruua-. I now consider this to be ambiguous on grounds of a reconsidered relative chronology. If one accepts that *a in *arwara $\bar{a}$ - 'plant(s)' < ${ }^{*} \mathrm{H}_{2} \mathrm{rH}_{3}$-uér-e $\mathrm{H}_{2}$ - must have been coloured to $u$ in the course of a Young Avestan sound change affecting all schwa's / [+labial], [+labial] (cf. brātruiia- $<*$ *w), one is led to propose that $* \partial^{\bar{w}}>$ $* u$, which would of course by necessity yield YAv. *turwja- < ${ }^{*} t \partial^{w} r w j a-$, in which the apparent loss of the segmental ${ }^{*} w$ must then be explained. But the change of $* w$ to zero through a palatalised ${ }^{*} w^{\prime}$ is only really unambiguously observable in the late Young Avestan sequences $* u w j e \bar{e}<*$ wai such as OAv. mruiie $<*$ mruwai, YAv. uiie $<* u w a i<* u b a i$ 'both' etc., whereas both *turja- and *pawrjacan also rather convincingly be explained as the result of early metathesis $*_{w r}>*_{r w} / \mathrm{V}_{\mathrm{j}}$ (cf. de Vaan 2003, §24.3). If the *u in 
*turja- is understood as the reflex of * $\partial w$ rather than $* \partial^{w}$, its length is easily accounted for as the result of secondary dissimilatory lengthening comparable to the situation in the vrddhi-derivative $\bar{a} h \bar{u}^{i} r i-$ 'ahuric' < *ahhuri- $\leftarrow$ ahura- or $\bar{a} x t \bar{u}^{i} r \bar{r} m$ 'fourth time' $<*_{-} k^{u}$ tur-íio- (see Kümmel 2007b: 275, cf. de Vaan 2003: 302-303 for the material, although with a different view on the specific development of $t \bar{u}^{i}$ riia-). If this is so, the YAv. D/Abl. pl. nuruiio will most economically be taken to reflect its prima facie sequence [nurujō] rather than stand for [nuruwijō] with simplified spelling (cf. OAv. pa\{o\} $\}^{u}$ ruiia $-<{ }^{*}$ pa $a^{w}$ ruwija $-<{ }^{*}$ pa ${ }^{w}$ rwija- $<{ }^{*}$ parwija- $)$, and appears to be derivable directly from *nərujo (by way of $* z>u$ / $\mathrm{C}_{0} \mathrm{u}$ as in $s^{u}$ runao- $<* s^{2}$ runao-; ${ }^{+}$naruiiō and nar biiō being very recent restorations) $<*$ narwjoh with what appears to be regular vocalisation of $* w>* u / \mathrm{r}_{\text {_.j.jV }}$ (this would also effectively explain the conspicuous difference between nuruiiō $<*^{*}$ narujō and ga ${ }^{u}$ ruuaiia $-<$ *garuwaja $<*$ garwaja-, which would otherwise only be explicable in terms of an assumed restoration of the $\partial r$-sequence in the latter). ${ }^{12}$ The reason for the seemingly aberrant treatment of a *VrwjV sequence naturally lies, as has been recognised (cf. de Vaan 2003: 519 and passim), in the fact that in this case the labial-velar approximant developed secondarily (and, crucially, after the change of either *arwj to $* \partial^{w} r w j>* \bar{u} r j$, or, what is likelier, ${ }^{*} \partial r w j>* \partial w r j>$ $* u r j$ ) from $* \beta$. Contrary to de Vaan 2005: 665, ft. 2, however, I find it very problematic to assume that the difference between YAv. garəßa- 'womb' < * gárb ${ }^{h} a$ - and ga ruuaiia- 'grab' $<* g^{h} r b H_{2}-n-H_{2}-$ iéló- is due to the lenited bilabial in the latter case being postvocalic, as this would imply Avestan *arz $<* r$ either to be earlier than the general development of anaptyxis or else still vocalic (which, however, is still quite possible). Rather, the early approximantisation in the case of the bilabial spirant / or $-\mathrm{V}^{\{-1\}}, \mathrm{j}^{13}$ (as opposed to /

${ }^{12}$ This will of course depend on the relative chronology of $* \beta>* w$ in relation to ${ }^{*} r^{w}>{ }^{* w} r$. If the labialisation of ${ }^{*} r$ is older than the latter change, then *garwaja- will have acquired its epenthetic $u$ after the change of ${ }^{*} C w>* C u w$ (for ${ }^{u} r<* r u$ cf. ${ }^{u} r \bar{u}-r a o \delta-<* H_{l} l u-H_{l} l o ́ u d^{h}$-). If the reverse chronology obtained, ga ruuaiia- for expected *gurwaja- $<*$ gaw rwaja- (vs. *narujah $<*$ narwjah), alongside *urwara $\bar{a}-<*$ w rwara $\bar{a}$, can of course only be justified as a case of secondary remodelling *gurwaja- $\rightarrow{ }^{*}$ garwaja- $>$ *garuwaja- $>*^{*}$ ga ruwaja- (which in this case would be earlier than ${ }^{+}$nəruiiō).

${ }^{13}$ The environment is comparable to the more general conditioning in purely intervocalic position $\mathrm{V} \_\mathrm{V}\{-\mathbf{i}\}, \mathrm{j}$. Incidentally, the surprising synchronic D/Abl. pl. form $a^{i} \beta i i \overline{\bar{o}}$ 'to the waters' $<* a b j a h<* H_{2} e ́ p-b^{h} i a s$ 
ar $\mathrm{V}, \mathrm{j}$ ) will have been a natural cause of tongue retraction induced by the preceding mid central vowel, so that *narßjah $>*^{*}$ narwjo, whence *narujo.

\section{References}

EDIL = Rastorgueva, V. S., Edel'man, D. I. 2000-2015: Etimologicheskiy slovar' iranskikh yazykov [Etymological Dictionary of the Iranian Languages]. Moscow.

ЭСИЯ = Расторгуева, В. С., Эдельман, Д. И. 2000-2015: Этимологический словарь иранских языков. Москва: Издательская фирма Восточная литература РАН.

Hintze, H. 1994: Der Zamyād-Yašt. Wiesbaden: Dr. Ludwig Reichert Verlag.

Hoffmann, K. 1976: Zur Flexion von -vant-/-mant-. In: Aufsätze zur Indoiranistik. Band 2. Johanna Narten (ed.). Wiesbaden: Dr. Ludwig Reichert Verlag, 555-556.

Hoffmann K., Narten J. 1989: Der sasanidische Archetypus. Wiesbaden: Dr. Ludwig Reichert Verlag.

JamaspAsa, K. M. 1982: Aogəmadaēcāa. A Zoroastrian Liturgy. Wien: Verlag der österreichischen Akademie der Wissenschaften.

Jamison, S. W. 1991: A Cart, an Ox, and the Perfect Participle in Vedic. Münchener Studien zur Sprachwissenschaft 52, 77-100.

Kellens J., Pirart E. 1988: Les textes vieil-avestiques. Vol. 1: Introduction, texte et traduction. Wiesbaden: Dr. Ludwig Reichert Verlag.

Kümmel, M. J. 2004: The development of laryngeals in Indo-Iranian. The sound of Indo-European 3, Opava 2014. Handout.

Kümmel, M. J. 2007a: Konsonantenwandel. Bausteine zu einer Typologie des Lautwandels und ihre Konsequenzen für die vergleichende Rekonstruktion. Dr. Ludwig Reichert Verlag.

Kümmel, M. J. 2007b: Review of de Vaan, M. C. The Avestan Vowels. Indo-Iranian Journal 50/3. 273-283.

Lipp, R. 2009: Die indogermanischen und einzelsprachlichen Palatale im Indoiranischen. Band 1: Neurekonstruktion, Nuristan-Sprachen, Genese der indoiranischen Retroflexe, Indoarisch von Mitanni. Heidelberg: Universitätsverlag Winter.

Lubotsky, A. 2002: The Indo-Iranian word for 'shank, shin'. Journal of the American Oriental Society 122, 318-324.

for expected *aoiio <*awjo (cf. de Vaan 2005: 670, 678), for the development of which cf. YAv. yüšmaoiiō < *iušmabias (with anlauting *i by analogical extension from the nominative and secondary *-bias for PIIr. $*_{-} b^{h} i a \leftarrow$ PIE $*-b^{h} i$ by directivisation, levelled in from the demonstratives and $/$ or the nominal declension) $<* u=s-m e ́-b^{h} i$, or rather $* a^{i} b i i \bar{o}$ with a restored ending, is best explained as owing its ${ }^{i} \beta i i \bar{o}$ to a morphonologically controlled restitution based on the nominative singular $\bar{a} f$, so that the newly restored alternation now appeared as $f \sim \beta \leftarrow{ }^{*} w$ rather than ${ }^{*} f \sim b$ $\leftarrow{ }^{*} w$. 
Narten, J. 1982: Die Aməș̆a Spəṇtas im Avesta. Wiesbaden: Dr. Ludwig Reichert Verlag.

Repanšek, L. 2018: Miscellanea Avestica et Palaeopersica. Indoevropeiskoe yazykoznanie i klassicheskaya filologiya [Indo-European linguistics and classical philology] 22, 1132-1149.

Schindler, J. 1982: Zum Nom. Sing. m. der nt-Partizipien im Jungavestischen. In: Investigationes philologicae et comparativae. Gedenkschrift für Heinz Kronasser. E. Neu (ed.). Wiesbaden: Harrasowitz Verlag, 186-209.

de Vaan, M. A. C. 2003: The Avestan Vowels. Amsterdam, New York: Rodopi.

de Vaan, M. A. C. 2005: The reflex of intervocalic *b in Avestan. In: Indogermanica. Festschrift Gert Klingenschmitt. Indische, iranische und indogermanische Studien dem verehrten Jubilar dargebracht zu seinem fünfundsechzigsten Geburtstag. Günter Schweiger (ed.). Taimering: Schweiger VWT-Verlag, 665-679. 